\title{
Antioxidative Glucosides from the Fruits of Ligustrum lucidum
}

\author{
Zhen-Dan He, ${ }^{a}$ Paul Pui-Hay But, ${ }^{*}, a$ Tak-Wah Dominic Chan, ${ }^{a}$ Hui Dong, ${ }^{a}$ Hong-Xi Xu, ${ }^{a}$ \\ Ching-Po LAU, ${ }^{a}$ and Han-Dong SuN ${ }^{b}$ \\ Departments of Biology and Chemistry and Institute of Chinese Medicine, The Chinese University of Hong Kong, ${ }^{a}$ Hong \\ Kong and Kunming Institute of Botany, Academia Sinica, ${ }^{b}$ Kunming 650204, Yunnan, P. R. China. \\ Received February 2, 2001; accepted March 24, 2001
}

\begin{abstract}
The ethanol extract of the fruits of Ligustrum lucidum was shown to have inhibitory effects on the hemolysis of red blood cells induced by 2,2'-azo-bis-(2-amidinopropane) dihydrochloride. Bioassay-guided analysis led to the isolation of ten secoiridoid glucosides. Two of them were new, lucidumosides $C$ and $D$. Their structures were elucidated by spectroscopic methods. The other eight compounds were identified as oleoside dimethyl ester, ligustroside, oleuropein, nuezhenide, isonuezhenide, neonuezhenide, lucidumoside $A$ and lucidumoside B. Five compounds, oleoside dimethyl ester, oleuropein, neonuezhenide, lucidumoside $B$ and lucidumoside $C$, exhibited strong antioxidant effect against hemolysis of red blood cells induced by free radicals.
\end{abstract}

Key words Ligustrum lucidum; Oleaceae; antioxidant; lucidumoside C; lucidumoside D

The metabolic processes in the human body, inevitably, often produce harmful free radicals. These free radicals have been shown to possibly contribute to aging and various diseases, such as atherosclerosis and cancer. ${ }^{1-2)}$ Therefore, it is important to identify effective radical scavengers to help relieve the damaging effects of free radicals. Our screening program for potent antioxidants from natural products have confirmed that polyphenolic compounds present in foods of plant origin do have strong radical scavenging and oxidationinhibiting effects. For example, the phenylethanoid glycosides from Brandisia hancei were found to have potent antioxidative properties. ${ }^{3)}$

Recently, our attention focused on the fruit of Ligustrum lucidum Aıт. (Oleaceae), which is known as "Nuzhenzi" in China. It is commonly used in Chinese medicine to supplement "kidneys", nourish "yin", strengthen liver and clear vision. ${ }^{4}$ Previous studies reported that the fruit of L. lucidum has immunomodulatory, ${ }^{5)}$ hypolipemic, ${ }^{6}$ antiinflammatory, ${ }^{7)}$ hepatoprotective, ${ }^{8)}$ antitumor ${ }^{9}$ and antiaging effects. ${ }^{10)}$ Related species of the same genus showed inhibitory effect on acyl CoA cholesteryl acyltransferase, ${ }^{11)}$ and immunomodulatory ${ }^{12)}$ and anticomplementary activities. ${ }^{13)}$ These biological effects appear to support some of the ethnomedical claims. Chemical studies have found volatile components, triterpenes, flavonoids, secoiridoid glucosides, and phenolic compounds from this plant, and constituents such as phenylethanoids, monoterpenes, and secoiridoid glucosides from other Ligustrum species. ${ }^{11,14-19)}$

In our screening program, ethanol extract of the fruits of $L$. lucidum showed antioxidative effect. Through bioassayguided analysis, ten secoiridoid glucosides were isolated from the active fractions. Two of the secoiridoid glucosides, lucidumosides C (9) and D (10), were new. Here we report the antioxidative activity of these constituents of Nuzhenzi against hemolysis of red blood cells (RBC) induced by free radicals, and also the structure elucidation of compounds 9 and $\mathbf{1 0}$.

The fruits of $L$. lucidum were extracted with ethanol and the ethanol extract showed significant inhibitory effects $\left(\mathrm{IC}_{50}=125 \mu \mathrm{g} / \mathrm{ml}\right)$ on the hemolysis of $\mathrm{RBC}$ induced by free radicals (Fig. 1). The ethanol extract was partitioned with water into an aqueous fraction (A) and an insoluble fraction
(B). The bioactivity of the ethanol extract against hemolysis of RBC test system was found concentrated in fraction A $\left(\mathrm{IC}_{50}=40 \mu \mathrm{g} / \mathrm{ml}\right)$. This fraction A was chromatographed on a porous polymer gel D-101 column with water, $60 \%$ aqueous ethanol and ethanol, to give fractions A1, A2 and A3 (Fig. 2). The biological activity was found concentrated in fraction $\mathrm{A} 2, \mathrm{IC}_{50}$ being $31 \mu \mathrm{g} / \mathrm{ml}$. From the active fraction A2, two new secoiridoid glucosides, lucidumosides $C(\mathbf{9})$ and D (10), were isolated together with eight known secoiridoid glucosides, oleoside dimethyl ester (1), ligustroside (2), oleuropein (3), nuezhenide (4), isonuezhenid (5), neonuezhenide (6), lucidumoside A (7) and lucidumoside B (8). Compounds $\mathbf{1}-\mathbf{8}$ were identified by comparison of spectral data with reported data. $^{18)}$

Compound 9 was obtained as an amorphous powder, $[\alpha]_{\mathrm{D}}^{15}$ $-112^{\circ}(\mathrm{MeOH})$. Its molecular formula was identified as $\mathrm{C}_{27} \mathrm{H}_{36} \mathrm{O}_{14}$ from its ESI-MS spectrum $\left(\mathrm{m} / z 583[\mathrm{M}-\mathrm{H}]^{-}\right)$and HR-FAB mass spectrum $\left(\mathrm{m} / \mathrm{z} 585.5817[\mathrm{M}+\mathrm{H}]^{+}\right)$. The presence of an aromatic moiety and a conjugated ester group was indicated by the absorptions in the UV $(235,282 \mathrm{~nm})$ and IR $\left(1640,1450 \mathrm{~cm}^{-1}\right)$ spectra of 9. The ${ }^{1} \mathrm{H}-\mathrm{NMR}$ spectrum showed the following signals due to a feature oleosidic aglycone moiety: an olefinic proton $[\delta 7.52(1 \mathrm{H}, \mathrm{s}, \mathrm{H}-3)]$, an acetalcarbinol proton $[\delta 5.92(1 \mathrm{H}, \mathrm{s}, \mathrm{H}-1)]$, three olefinic methyl protons $\left[\delta 1.70\left(3 \mathrm{H}, \mathrm{d}, J=6.9 \mathrm{~Hz}, \mathrm{H}_{3}-10\right)\right]$ and an olefinic proton $[\delta 6.10(1 \mathrm{H}, \mathrm{q}, J=6.9 \mathrm{~Hz}, \mathrm{H}-8)]$. Its ${ }^{1} \mathrm{H}-\mathrm{NMR}$ spectrum (Table 1) indicated an ABX system which belongs to the phenyl. ${ }^{1} \mathrm{H}-\mathrm{NMR}$ signals of an anomeric proton at $\delta$ $4.81(1 \mathrm{H}, \mathrm{d}, J=7.8 \mathrm{~Hz})$ is consistent with the configuration for $\beta$-D-glucose. When comparing the ${ }^{1} \mathrm{H}$ signals of 9 with those of $\mathbf{3}$, their ${ }^{1} \mathrm{H}-\mathrm{NMR}$ signals were similar, but the signals of $\mathrm{H}-\alpha$ and $\beta$ in the phenethyl moiety were different. Also, there was one more set of ethoxy which was shown at $\delta$ $1.16(3 \mathrm{H}, \mathrm{t}, J=5.4 \mathrm{~Hz})$ and $\delta 3.44(2 \mathrm{H}, \mathrm{m})$ in 9.

As the signal of $\mathrm{CD}_{3} \mathrm{OD}$ solvent overlapped with other signals, the 2D NMR spectrum of glucoside 9 was measured in pyridine- $d_{5}$. The signals of proton and carbon of 9 were exacted by ${ }^{1} \mathrm{H}-{ }^{1} \mathrm{H}$ and ${ }^{1} \mathrm{H}-{ }^{13} \mathrm{C}$ COSY experiment. The chemical shift of $\mathrm{H}-2 \beta$ in phenylethyl moiety of 9 shifted downfield from $\delta 2.85(2 \mathrm{H}, \mathrm{t}, J=6.7 \mathrm{~Hz})$ to $\delta 4.59(1 \mathrm{H}, \mathrm{t}, J=7.1 \mathrm{~Hz})$ as compared with those of 3 . Furthermore, in the HMBC experiment, the correlation between $\mathrm{H}-1^{\prime}(\delta 5.47)$ of the glucose 
unit and the $\mathrm{C}-1$ atom $(\delta 94.9)$ of the aglycone moiety, three methoxy protons $(\delta 3.65)$ and the $\mathrm{C}-11$ of the aglycone moiety, $\mathrm{H}-\alpha(\delta 4.33)$ of the phenylethyl moiety and the C-7

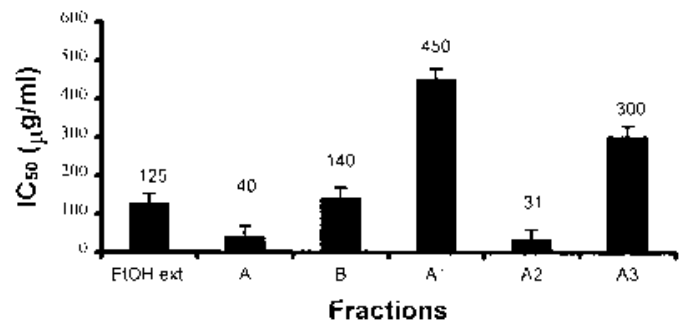

Fig. 1. Inhibitory Effect $\mathrm{IC}_{50}$ of Fractions from the Fruits of L. lucidum on AAPH-Induced Hemolysis of Rat RBC in vitro
( $\delta$ 171.5) of the aglycone unit, the H- $\beta(\delta 4.59)$ of the phenylethyl moiety and the $-\mathrm{OCH}_{2} \mathrm{CH}_{3}(\delta$ 64.4) were observed. Additional significant long-range correlation confirming the proposed structure were shown in Fig. 4. The structure of this glucoside was concluded to be as shown in 9. This new secoiridoidic glucoside is designated as lucidumoside $\mathrm{C}$.

Compound $\mathbf{1 0}$ was obtained as an amorphous powder. The ESI-MS of compound $\mathbf{1 0}$ exhibited a pseudomolecular ion $[\mathrm{M}-\mathrm{H}]^{-}$at $\mathrm{m} / \mathrm{z} 567$ and its HR-FAB mass spectrum $\mathrm{m} / \mathrm{z}$ $569.5721[\mathrm{M}+\mathrm{H}]^{+}$, compatible with the molecular formula $\mathrm{C}_{27} \mathrm{H}_{36} \mathrm{O}_{13}$, The UV $(278 \mathrm{~nm})$ and IR $\left(1520 \mathrm{~cm}^{-1}\right)$ spectra of $\mathbf{1 0}$ displayed the presence of an aromatic moiety. Its ${ }^{1} \mathrm{H}$ spectrum and ${ }^{13} \mathrm{C}$ DEPT experiment exhibited 3,4-dihy-

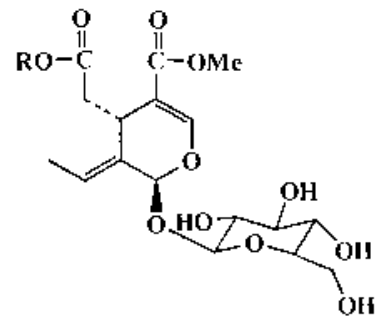

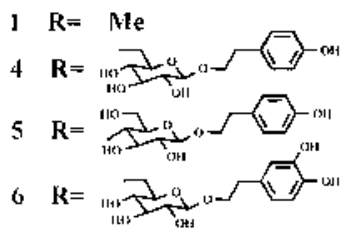

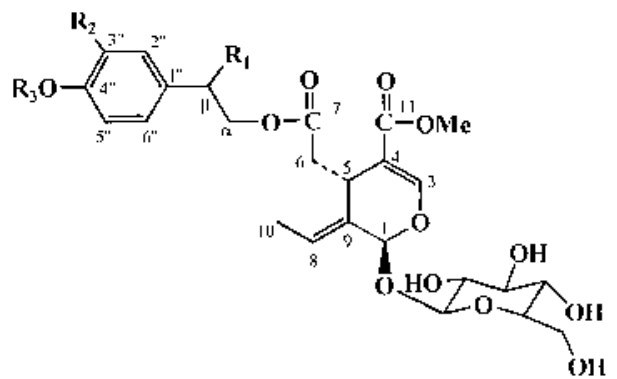

$$
\begin{array}{llll} 
& \mathrm{R}_{1} & \mathrm{R}_{2} & \mathrm{R}_{3} \\
2 & \mathrm{H} & \mathrm{H} & \mathrm{II} \\
3 & \mathrm{H} & \mathrm{OH} & \mathrm{H} \\
9 & \mathrm{OLt} & \mathrm{OH} & \mathrm{H} \\
10 & \mathrm{H} & \mathrm{OMe} & \mathrm{Me}
\end{array}
$$

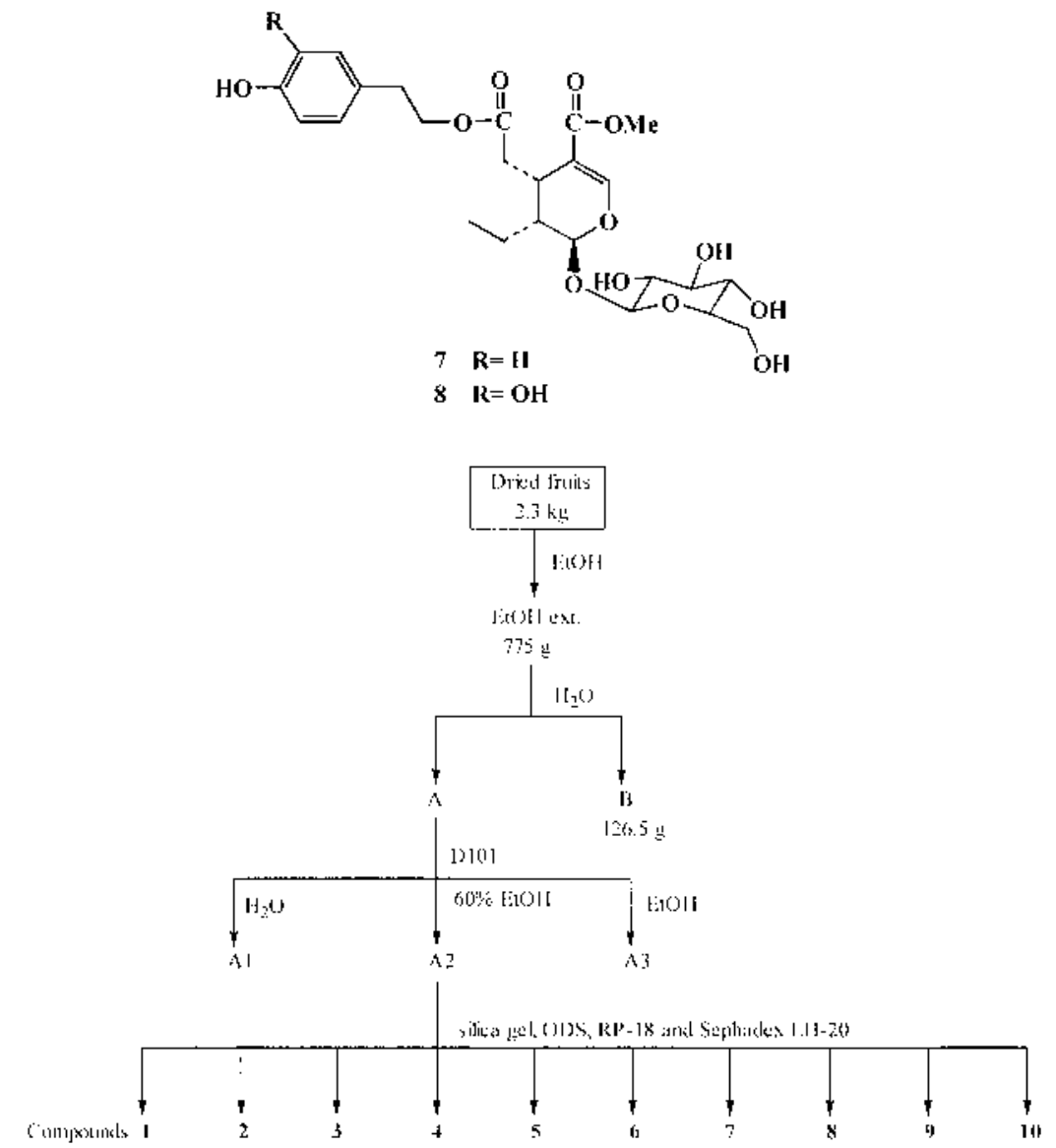

Fig. 2. Isolation Procedure for the Constituents from the Fruits of L. lucidum 
Table 1. ${ }^{1} \mathrm{H}-\mathrm{NMR}$ Spectral Data of Secoiridoid Glucosides 3, 9, and $\mathbf{1 0}$ in $\mathrm{CD}_{3} \mathrm{OD}^{a)}$

\begin{tabular}{|c|c|c|c|c|}
\hline $\mathrm{H}$ & 3 & 9 & $9^{b)}$ & 10 \\
\hline \multicolumn{5}{|l|}{ Aglycone } \\
\hline 1 & $5.92(1 \mathrm{H}, \mathrm{d}, 1.5)$ & $5.92(1 \mathrm{H}$, br s, H-1) & $6.34(1 \mathrm{H}, \mathrm{s})$ & $5.91(1 \mathrm{H}, \mathrm{s})$ \\
\hline 3 & $7.49(1 \mathrm{H}, \mathrm{s})$ & $7.52(1 \mathrm{H}, \mathrm{s})$ & $7.70(1 \mathrm{H}, \mathrm{s})$ & $7.50(1 \mathrm{H}, \mathrm{s})$ \\
\hline 5 & $3.92(1 \mathrm{H}, \mathrm{dd}, 4.2,9.1)$ & $4.36(1 \mathrm{H}, \mathrm{m})$ & $4.30(1 \mathrm{H}, \mathrm{m})$ & - \\
\hline \multirow[t]{2}{*}{6} & $2.43(1 \mathrm{H}, \mathrm{dd}, 8.7,14.0)$ & $2.48(1 \mathrm{H}, \mathrm{dd}, 9.0,14.1)$ & $2.53(1 \mathrm{H}, \mathrm{dd}, 9.1,14.3)$ & $2.42(1 \mathrm{H}, \mathrm{dd}, 8.9,14.0)$ \\
\hline & $2.83(1 \mathrm{H}, \mathrm{dd}, 4.2,9.1)$ & $2.72(1 \mathrm{H}, \mathrm{dd}, 3.2,14.1)$ & $2.86(1 \mathrm{H}, \mathrm{dd}, 3.2,14.3)$ & $2.78(1 \mathrm{H}, \mathrm{dd}, 4.2,14.0)$ \\
\hline 8 & $6.05(1 \mathrm{H}, \mathrm{q}, 6.9)$ & $6.10(1 \mathrm{H}, \mathrm{q}, 6.9)$ & $6.19(1 \mathrm{H}$, br q, 6.3) & $6.08(1 \mathrm{H}, \mathrm{q}, 7.3)$ \\
\hline \multicolumn{5}{|c|}{ की } \\
\hline 10 & $1.64(3 \mathrm{H}, \mathrm{d}, 6.9)$ & $1.70(3 \mathrm{H}, \mathrm{d}, 6.9)$ & $1.71(3 \mathrm{H}, \mathrm{d}, 6.3)$ & $1.63(3 \mathrm{H}, \mathrm{d}, 7.1)$ \\
\hline $\mathrm{OMe}$ & $3.69(3 \mathrm{H}, \mathrm{s})$ & $3.72(3 \mathrm{H}, \mathrm{s})$ & $3.65(3 \mathrm{H}, \mathrm{s})$ & $3.71(3 \mathrm{H}, \mathrm{s})$ \\
\hline \multirow[t]{2}{*}{$\mathrm{ArOMe}$} & & & & $3.84(3 \mathrm{H}, \mathrm{s})$ \\
\hline & & & & $3.85(3 \mathrm{H}, \mathrm{s})$ \\
\hline \multicolumn{5}{|l|}{ Glucose } \\
\hline $1^{\prime}$ & $4.78(1 \mathrm{H}, \mathrm{d}, 7.8)$ & $4.81(1 \mathrm{H}, \mathrm{d}, 7.8)$ & $5.47(1 \mathrm{H}, \mathrm{d}, 7.4)$ & $4.83(1 \mathrm{H}, \mathrm{d}, 7.7)$ \\
\hline \multicolumn{5}{|l|}{ Phenylethyl } \\
\hline$\alpha$ & $4.09(2 \mathrm{H}, \mathrm{t}, 6.8)$ & $4.01-3.90(2 \mathrm{H}, \mathrm{m})$ & $4.33(2 \mathrm{H}, \mathrm{m})$ & $4.23(2 \mathrm{H}, \mathrm{t}, 6.9)$ \\
\hline$\beta$ & $2.85(2 \mathrm{H}, \mathrm{t}, 6.8)$ & $4.58(2 \mathrm{H}, \mathrm{t}, 7.0)$ & $4.59(2 \mathrm{H}, \mathrm{t}, 7.1)$ & $2.90(2 \mathrm{H}, \mathrm{t}, 6.9)$ \\
\hline $2^{\prime \prime}$ & $6.75(1 \mathrm{H}, \mathrm{s})$ & $6.78(1 \mathrm{H}, \mathrm{s})$ & $7.38(1 \mathrm{H}, \mathrm{s})$ & $6.79(1 \mathrm{H}, \mathrm{s})$ \\
\hline $5^{\prime \prime}$ & $6.78(1 \mathrm{H}, \mathrm{d}, 7.9)$ & $6.77(1 \mathrm{H}, \mathrm{d}, 8.7)$ & $7.28(1 \mathrm{H}, \mathrm{d}, 8.7)$ & $6.78(1 \mathrm{H}, \mathrm{d}, 8.7)$ \\
\hline $6^{\prime \prime}$ & $6.58(1 \mathrm{H}, \mathrm{d}, 7.9)$ & $6.66(1 \mathrm{H}, \mathrm{d}, 8.7)$ & $6.95(1 \mathrm{H}, \mathrm{d}, 8.7)$ & $6.67(1 \mathrm{H}, \mathrm{d}, 8.7)$ \\
\hline \multirow[t]{3}{*}{$\mathrm{OCH}_{2} \mathrm{CH}_{3}$} & & $1.16(3 \mathrm{H}, \mathrm{t}, 5.4)$ & $1.12(3 \mathrm{H}, \mathrm{dd}, 6.9,13.9)$ & \\
\hline & & $3.44(2 \mathrm{H}, \mathrm{m})$ & $3.40(1 \mathrm{H}, \mathrm{dq}, 7.3,13.9)$ & \\
\hline & & & $3.51(1 \mathrm{H}, \mathrm{dq}, 7.3,6.9)$ & \\
\hline
\end{tabular}

a) Coupling constants ( $J$ values in Hz) are shown in parenthesis; b) Column values are measured in $\mathrm{C}_{5} \mathrm{D}_{5} \mathrm{~N}$.

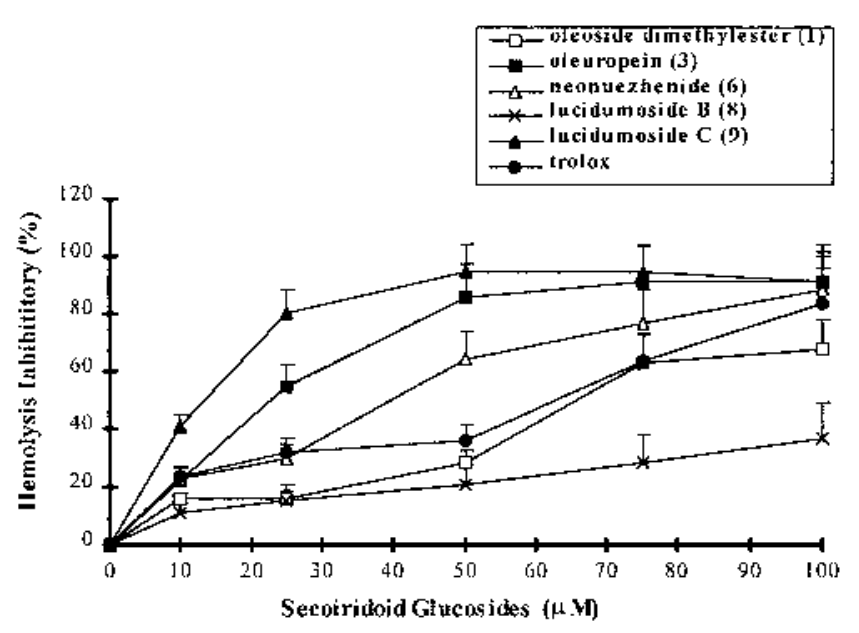

Fig. 3. Inhibitory Effect of Individual Secoiridoid Glucosides on AAPHInduced Hemolysis of Rat RBC in vitro

All data were expressed as mean \pm S.E.M. $(n=4)$.

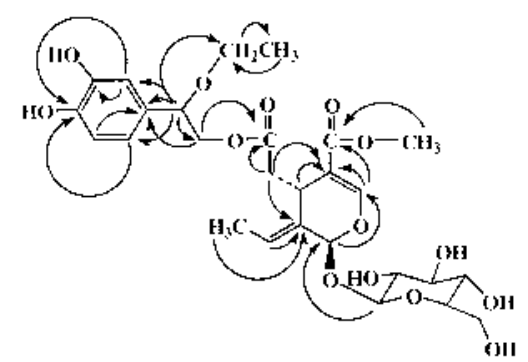

Fig. 4. Selected Heteronuclear Multiple Bond Correlation (HMBC) for 9 Arrows point from proton to carbon.

doxyphenylethyl group by the observation of typical ABX spin system and six aromatic carbon $[\delta 130.5(\mathrm{C}), 112.1$ $(\mathrm{CH}), 149.6(\mathrm{C}), 147.6(\mathrm{C}), 113.1(\mathrm{CH}), 121.8(\mathrm{CH})]$, in ad-
Table 2. ${ }^{13} \mathrm{C}-\mathrm{NMR}$ Spectral Data of Glucosides 3, 9, and $\mathbf{1 0}$ in $\mathrm{CD}_{3} \mathrm{OD}$

\begin{tabular}{|c|c|c|c|c|}
\hline $\mathrm{C}$ & 3 & 9 & $9^{a)}$ & 10 \\
\hline \multicolumn{5}{|l|}{ Aglycone } \\
\hline 1 & 95.3 & 93.7 & 94.9 & 95.1 \\
\hline 3 & 155.1 & 153.8 & 154.2 & 154.8 \\
\hline 4 & 109.4 & 107.9 & 108.9 & 109.6 \\
\hline 5 & 31.6 & 30.4 & 31.0 & 31.6 \\
\hline 6 & 42.9 & 39.7 & 40.7 & 42.5 \\
\hline 7 & 173.1 & 171.7 & 171.5 & 173.4 \\
\hline 8 & 124.9 & 123.6 & 124.1 & 124.6 \\
\hline 9 & 130.4 & 128.9 & 130.5 & 130.3 \\
\hline 10 & 13.5 & 12.4 & 13.4 & 14.1 \\
\hline 11 & 168.8 & 167.3 & 167.0 & 168.7 \\
\hline \multirow[t]{3}{*}{$\mathrm{OMe}$} & 51.8 & 50.7 & 51.3 & 51.3 \\
\hline & & & & 56.7 \\
\hline & & & & 56.8 \\
\hline \multicolumn{5}{|l|}{ Glucose } \\
\hline $1^{\prime}$ & 100.9 & 99.3 & 101.4 & 99.5 \\
\hline $2^{\prime}$ & 74.5 & 73.3 & 75.0 & 74.1 \\
\hline $3^{\prime}$ & 77.8 & 76.4 & 78.4 & 78.4 \\
\hline $4^{\prime}$ & 71.6 & 70.0 & 71.6 & 71.8 \\
\hline $5^{\prime}$ & 78.6 & 76.9 & 78.9 & 78.5 \\
\hline $6^{\prime}$ & 62.5 & 61.3 & 62.7 & 62.4 \\
\hline \multicolumn{5}{|c|}{ Phenylethyl } \\
\hline$\alpha$ & 66.8 & 67.9 & 68.9 & 66.5 \\
\hline$\beta$ & 36.2 & 79.2 & 79.9 & 36.1 \\
\hline $1^{\prime \prime}$ & 131.2 & 129.8 & 131.0 & 130.5 \\
\hline $2^{\prime \prime}$ & 117.0 & 114.9 & 116.6 & 112.1 \\
\hline $3^{\prime \prime}$ & 146.7 & 145.0 & 147.4 & 149.6 \\
\hline $4^{\prime \prime}$ & 144.6 & 144.9 & 147.2 & 147.6 \\
\hline $5^{\prime \prime}$ & 116.3 & 113.4 & 115.3 & 113.1 \\
\hline $6^{\prime \prime}$ & 121.2 & 118.3 & 119.0 & 121.8 \\
\hline \multirow[t]{2}{*}{$\mathrm{OCH}_{2} \mathrm{CH}_{3}$} & & 14.3 & 15.6 & \\
\hline & & 63.9 & 64.4 & \\
\hline
\end{tabular}

a) Column values are measured in $\mathrm{C}_{5} \mathrm{D}_{5} \mathrm{~N}$.

dition to the occurrence of a $\mathrm{CH}_{2} \mathrm{CH}_{2} \mathrm{O}$ group $[\delta 4.23$ (t, $J=6.9 \mathrm{~Hz})$ and $2.90(\mathrm{t}, J=6.9 \mathrm{~Hz})]$. The ${ }^{1} \mathrm{H}-\mathrm{NMR}$ spectrum in Table 1 exhibited one set of signals for a methoxy group, 
two olefinic protons $(\mathrm{H}-3, \mathrm{H}-8)$, an acetalcarbinol proton $(\mathrm{H}-$ $1)$, and an olefinic methyl group $\left(\mathrm{H}_{3}-10\right)$ signals. ${ }^{1} \mathrm{H}-\mathrm{NMR}$ signals of an anomeric proton at $\delta 4.83(1 \mathrm{H}, \mathrm{d}, J=7.7 \mathrm{~Hz})$ is consistent with configuration for $\beta$-D-glucose. These spectral features proved the presence of an identical moiety of oleoside dimethyl ester (1) in compound 10. The ${ }^{1} \mathrm{H}-$ and ${ }^{13} \mathrm{C}$ NMR spectra of glucoside $\mathbf{1 0}$ were very similar to those of $\mathbf{3}$ except for the appearance of signals of two methoxy group in 3 (Tables 1 and 2). By comparison of ${ }^{13} \mathrm{C}-\mathrm{NMR}$ signals of $\mathbf{1 0}$ with those of 3 , the chemical shift assignable to C-3" and 4" of 3 shifted downfield 2.9 and $3.0 \mathrm{ppm}$, respectively. The two methoxy group should be located at the C-3" and 4 " position of the phenylethyl moiety in 10. Thus, the structure of this glucoside was demonstrated as 10; it is named lucidumoside D.

Compounds $\mathbf{1}-\mathbf{1 0}$ were tested for their effect on free radical induced hemolysis of RBC. Our results demonstrated that compounds $\mathbf{3}, \mathbf{6}$ and $\mathbf{9}$ showed strong antioxidant effects $\left(\mathrm{IC}_{50}=9.3-37.5 \mu \mathrm{M}\right)$. Compound 9 exhibited the most potent activity $\left(\mathrm{IC}_{50}=9.3 \mu \mathrm{M}\right)$, which was 4 times stronger than that of trolox. The activity of compounds $\mathbf{3}$ and $\mathbf{6}$ was also stronger than that of trolox, but slightly weaker than that of compount 9. Compounds $\mathbf{1}$ and $\mathbf{8}$ showed weaker activity than trolox. The $\mathrm{IC}_{50}$ of compounds $\mathbf{2}, \mathbf{4}, \mathbf{5}, \mathbf{7}$, and $\mathbf{1 0}$ exceeded $200 \mu \mathrm{M}$. These experimental results suggested that the hemolysis inhibitory effect of these compounds might be related to the number of their phenolic hydroxyl groups.

Additionally, 3 was recently reported to have antiviral effects. ${ }^{20)}$ It would be interesting to check if its antiviral effect is related to its antioxidant property and also if $\mathbf{9}$ has stronger antiviral function.

\section{Experimental}

Optical rotations were measured with a JASCO DIP-370 digital polarimeter. UV spectra were recorded using a Shimadzu UV-3100PC spectrophotometer. IR absorption spectra were obtained with an IR-450 instrument as a film on $\mathrm{KBr}$ disk. FAB-MS were recorded on VG Autospec 3000 system, and ESI-MS on Finnigan TSQ 7000. ${ }^{1} \mathrm{H}$ and ${ }^{13} \mathrm{C}$ spectra were obtained with Bruker 400 instrument operating at $400 \mathrm{MHz}$ for ${ }^{1} \mathrm{H}, 100 \mathrm{MHz}$ for ${ }^{13} \mathrm{C}$, respectively. Chemical shifts are reported in parts per million on the $\delta$ scale with TMS as the internal standard, and coupling constants are in Hertz. Column chromatographies were performed with silica gel (Qingdao Haiyang Chemical Group Co. Ltd., China), Chromatorex ODS (Fuji Silysia Chemical Ltd., Japan), D-101 (Tianjin Agricultural Chemical Co. Ltd., China), and Sephadex LH-20 (Pharmacia Fine Chemical Co. Ltd.). TLC were performed on precoated $\mathrm{Si}$ gel $60 \mathrm{~F}_{254}$ plates $\left(0.2 \mathrm{~mm}\right.$ thick, Merck) with $\mathrm{CHCl}_{3}-$ $\mathrm{MeOH}\left(10: 1,9: 1,8: 2\right.$, v/v) and RP-18 $\mathrm{F}_{254 \mathrm{~s}}(0.2 \mathrm{~mm}$ thick, Merck) with $\mathrm{MeOH}-\mathrm{H}_{2} \mathrm{O}(8: 2,7: 3,6: 4,6: 5, \mathrm{v} / \mathrm{v})$, and spots were detected by UV illumination and by spraying with $10 \%$ ethanolic $\mathrm{H}_{2} \mathrm{SO}_{4}$ reagent.

Plant Material Dry fruits of Ligustrum lucidum was bought from a Chinese medicine shop in Hong Kong. The voucher specimen (No. 20002367) was deposited in the Museum of Institute of Chinese Medicine, Chinese University of Hong Kong.

Extraction and Isolation The dried fruits $(2.30 \mathrm{~kg})$ of L. lucidum were extracted with EtOH $(51 \times 3)$. The EtOH extract $(50 \%$ inhibitory activity $\mathrm{IC}_{50}=125 \mu \mathrm{g} / \mathrm{ml}$ as shown in Fig. 1) was concentrated in vacuum to give a residue $(775.3 \mathrm{~g})$. The residue was dissolved in $\mathrm{H}_{2} \mathrm{O}(50 \mathrm{l})$, and divided into aqueous A and insoluble B parts. The aqueous $\mathrm{A}\left(\mathrm{IC}_{50}=40 \mu \mathrm{g} / \mathrm{ml}\right)$ was absorbed on D101 $(2 \mathrm{~kg})$ and then eluted with $\mathrm{H}_{2} \mathrm{O}(201), 60 \%$ EtOH aqueous (61) and EtOH (6 l) to afford three fractions, A1 (170.1 g), A2 (63.1 g), and A3 $(1.8 \mathrm{~g})$. Fraction A2 $\left(\mathrm{IC}_{50}=31.25 \mu \mathrm{g} / \mathrm{ml}\right)(28.4 \mathrm{~g})$ was developed on silica gel $(2 \mathrm{~kg})$ eluting with $\mathrm{CHCl}_{3}-\mathrm{MeOH}(8: 2)$ and then the silica gel in the column was divided equally into 18 fractions, each fraction was eluted with $\mathrm{MeOH}(300 \mathrm{ml})$ and concentrated. The 18 fractions were combined into six fractions, Frs. $1-6$, based on silica TLC $\left(\mathrm{CHCl}_{3}-\mathrm{MeOH}, 8: 2\right)$ results. The Fr. $1(1.11 \mathrm{~g})$ and Fr. $2(0.90 \mathrm{~g})$ were purified by Sephadex LH-20 eluting with $\mathrm{EtOH}-\mathrm{H}_{2} \mathrm{O}(6: 4)$ and then by silica gel eluting with $\mathrm{CHCl}_{3}-\mathrm{MeOH}$ to give oleoside dimethyl ester (1) (5.1 mg), lucidumoside A (7) (7.8 mg) and lucidumoside B (8) $(6.5 \mathrm{mg})$. The Fr. $3(1.08 \mathrm{~g})$ and Fr. 4 (1.41 g) were purified by silica gel $\left[\mathrm{CHCl}_{3}-\mathrm{MeOH}(9: 1)\right.$ as eluent] and then by ODS [MeOH$\left.\mathrm{H}_{2} \mathrm{O}(7: 3)\right]$ to afford ligustroside (2) $(190.0 \mathrm{mg})$, oleuropein $(3)(6.5 \mathrm{mg})$, lucidumoside C (9) (45.1 mg) and lucidumoside D (10) (19.8 mg). The Fr. 5 $(2.1 \mathrm{~g})$ was purified by Sephadex $\mathrm{LH}-20$ [EtOH- $\left.\mathrm{H}_{2} \mathrm{O}(6: 4)\right]$, silica gel $\left[\mathrm{CHCl}_{3}-\mathrm{MeOH}(8: 2)\right.$ and $\mathrm{ODS}\left[\mathrm{MeOH}-\mathrm{H}_{2} \mathrm{O}(6: 5)\right]$ to give nuezhenide (4) $(9.1 \mathrm{mg})$ and isonuezhenide (5) $(13.2 \mathrm{mg})$. The Fr. $6(1.5 \mathrm{~g})$ was chromatographed on Sephadex $\mathrm{LH}-20$ [MeOH$\left.-\mathrm{H}_{2} \mathrm{O}(6: 4)\right]$, and purified by silica gel $\left[\mathrm{CHCl}_{3}-\mathrm{MeOH}(8: 2)\right]$ and $\mathrm{Rp}-18\left[\mathrm{MeOH}-\mathrm{H}_{2} \mathrm{O}(6: 5)\right]$ to yield neonuezhenide (6) (20.1 mg).

Lucidumoside C (9): Powder, $[\alpha]_{\mathrm{D}}^{15}-112^{\circ}(c 0.22, \mathrm{MeOH})$; UV (EtOH) $\lambda_{\max }(\log \varepsilon) 235(4.10), 282(3.43) \mathrm{nm}$; IR (KBr) $v_{\max } 3400,1710,1640$, $1450,1390,1075 \mathrm{~cm}^{-1}$; The ${ }^{1} \mathrm{H}$ - and ${ }^{13} \mathrm{C}$-NMR spectral data (see Tables 1 and 2); ESI-MS $m / z 583[\mathrm{M}-\mathrm{H}]^{-}, 537[\mathrm{M}-\mathrm{OEt}-2 \mathrm{H}]^{-}, 421[\mathrm{M}-\mathrm{glc}]^{-}$; HR-FAB-MS $m / z$ : Found $585.5817[\mathrm{M}+\mathrm{H}]^{+}\left(\mathrm{C}_{27} \mathrm{H}_{37} \mathrm{O}_{14}\right.$ requires 585.5824).

Lucidumoside D (10): Powder, $[\alpha]_{\mathrm{D}}^{15}-143^{\circ}(c 0.32, \mathrm{MeOH})$; UV (EtOH) $\lambda_{\max }(\log \varepsilon) 232$ (4.00), $278(3.41) \mathrm{nm}$; IR (KBr) $v_{\max } 3400,1710,1640$, $1520,1390,1070 \mathrm{~cm}^{-1}$; The ${ }^{1} \mathrm{H}$ - and ${ }^{13} \mathrm{C}-\mathrm{NMR}$ spectral data (see Tables 1 and 2); ESI-MS $m / z 567[\mathrm{M}-\mathrm{H}]^{-}, 405[\mathrm{M}-\mathrm{glc}]^{-}$; HR-FAB-MS $m / z$ : Found $569.5721[\mathrm{M}+\mathrm{H}]^{+}\left(\mathrm{C}_{27} \mathrm{H}_{37} \mathrm{O}_{13}\right.$ requires 569.5830).

Hemolysis of RBC Rat blood from the abdominal aorta was collected. The RBC were separated form plasma by centrifugation at $2500 \mathrm{rpm}$ for $10 \mathrm{~min}$. The crude RBC were then washed three times with five volumes of phosphate buffered saline (PBS, pH 7.4). The packed RBC were then suspended in four volumes of PBS solution.

Oxidative hemolysis in RBC induced by a peroxyl radical initiatior, 2,2'azo-bis-(2-amidinopropane) dihydrochloride (AAPH), was chosen as a model for the peroxidative damage in biomembrane. Addition of AAPH to a suspension of RBC caused oxidation of lipids and proteins in cell membrane and thereby induced hemolysis. The AAPH-induced hemolysis in RBC is a function of incubation time and is proportional to the concentration of free radicals. The inhibitory effect against RBC hemolysis is also proportional to the concentration of antioxidants in the incubation mixture. Two milliliters of RBC suspension was mixed with $2 \mathrm{ml}$ of PBS solution containing varying amounts of glucosides. One milliliter of $400 \mathrm{~mm}$ AAPH in PBS solution was then added to the mixture. The incubation mixture was shaken gently in a water bath at $37^{\circ} \mathrm{C}$ for $3 \mathrm{~h}$. After incubation, $8 \mathrm{ml}$ of PBS solution was added into the reaction mixture followed by centrifugation at $3000 \mathrm{rpm}$ for $10 \mathrm{~min}$.

The absorbance $(A)$ of the supernatant at $540 \mathrm{~nm}$ was recorded in a Shimadzu 1201 spectrophotometer. Percentage inhibition was calculated by the following equation: \% inhibition $=\left[A_{\mathrm{ctl}}-A_{\text {sample }}\right] / A_{\text {ctt }}$, in which $A_{\text {sample }}$ is the absorbance of the sample containing glucoside and $A_{\mathrm{ctl}}$ is the absorbance of the control.

Acknowledgements Partial support was received from Industrial Support Fund (AF/281/97).

\section{References}

1) Halliwell B., Gutteridge J. M. C., "Free Radicals In Biology and Medicine," Oxford University Press, Oxford, 1999.

2) Lean M. E. J., Noroozi M., Kelly I., Burns J., Talwar D., Sattar N., Crozier A., Diabetes, 48, 176-181 (1999).

3) He Z. D., Lau K. M., Xu H. X., Li P. C., But P. P. H., J. Ethnopharm., 71, $483-486$ (2000).

4) Jiansu New College of Medicine, "The Dictionary of Chinese Medicine," Shanghai People's Press, Shanghai, 1977, pp. 237-239.

5) Dai Y., Han B. Q., Li P. Z., J. China Pharm. Univ., 18, 301-304 (1987).

6) Peng Y., Bian X. Y., Zhao S. Y., Gao Q. Y., Bull. Chin. Materia Medica, 8(3), 32-34 (1994).

7) Dai Y., Han B. Q., Meng Q. Y., Li P. Z., China J. Chin. Materia Medica, 14, 431-433 (1989).

8) Yin Y. S., Yu C. S., Chin. Trad. Patent Med., 15(9), 18-19 (1993).

9) Lau B. H. S., Ruckle H. C., Botolazzo T., Lui P. D., Cancer Biotherapy, 9, 153-161 (1994).

10) Zhao Y., Wen J., Sun Z. R., Zhongyi Yaoxuebao, 18(6), 47-48 (1990)

11) Fukuda T., Kitada Y., Chen X. M., Yang L., Miyase T., Chem. Pharm. Bull., 44, 2173-2176 (1996).

12) Baronikora S., Nagy M., Grancai D., Phytotherapy Res., 13, 692-695 (1999).

13) Pieroni A., Pachaly P., Huang Y., Van Poel B., Vlietinck A. J., J. Ethnopharm., 70, 213-217 (2000).

14) Inouye H., Nishioka T., Tetrahedron, 28, 4231- 4237 (1972). 
15) Garibodi P., Jommi F., Verotta L., Phytochemistry, 25, 865-869 (1986).

16) He Z. D., Liu Y. Q., Yang C. R., Acta Bot. Yannanica, 14, 328-336 (1992).

17) He Z. D., Ueda S., Akaji M., Fujita T., Inoue K., Yang C. R., Phytochemistry, 36, 709-716 (1994).
18) He Z. D., Dong H., Xu H. X., Ye W. C., Sun H. D., But P. P. H., Phytochemistry, 56, 327-330 (2001).

19) Tian J., Zhang H. J., Sun H. D., Chin. Chem. Lett., 7, 341-344 (1996).

20) Fredrickson W. R., U. S. Patent 6117844; Appl. No. 668324; September 12 (2000). 